\title{
Battling Blind Spots: Hours of Ser- vice Regulations and Contentious Mo- BILITIES IN THE BC-Based LONG HaUl TRUCKING INDUSTRY
}

AMIE McLeAN

Abstract. In this article, I explore arenas of contention in which long haul truckers' workplace mobilities are enmeshed. I critically analyze the grounded implications of Hours of Service (HoS) regulations, a primary regulatory mechanism for addressing the dangers posed by truck driver fatigue. I argue that HoS regulations enforce a neoliberal individualization of responsibility that fails to account for industry power dynamics or truckers' lived experiences of labour mobility. These dynamics add to concerns about the potential exploitation of migrant truck drivers, including through the Temporary Foreign Worker Program. Inasmuch as they fail to address the classed, gendered and racialized dynamics of trucking mobilities, HoS regulations are implicated in perpetuating hierarchies of power in the industry. As such, they are inadequate and - in contextually specific ways - counterproductive to promoting employment equity or overall public safety. These issues are particularly evident in the contentious politics of blame concerning heavy truck-involved collisions.

Keywords: Trucking, labour, mobility, neoliberalism, hours of service, regulation, deregulation

Résumé. Dans cet article, j'explore les éléments litigieux dans lesquels les mobilités de lieu de travail des conducteurs de grands routiers sont emmêlées. Je fais une analyse critique des implications ancrées de la réglementation des Heures de service (HdeS), un mécanisme de régulation principal pour aborder les dangers posés par la fatigue des conducteurs. J'avance que la réglementation de HdeS impose une individualisation néolibérale de responsabilité qui ne tient pas compte des dynamiques du pouvoir du secteur ou des expériences vécues de mobilité professionnelle des conducteurs. Ces dynamiques s'ajoutent aux préoccupations concernant une exploitation potentielle des conducteurs migrants, y compris par le biais du Programme des travailleurs étrangers temporaires. En plus de n'avoir pas réussi à traiter les dynamiques liées à la classe sociale, au sexe et à l'ethnie de la mobilité du secteur du camionnage, la réglementation 
de HdeS joue un rôle dans la pérennisation des hiérarchies du pouvoir dans le secteur. Elles sont inadéquates et échouent, de manières spécifiques au contexte, à promouvoir l'équité en matière d'emploi et la sécurité publique. Ces enjeux sont particulièrement évidents dans les litiges liés à la responsabilité dans les collisions impliquant des poids lourds.

Mots clés: Camionnage, main-d'œuvre, mobilité, néolibéralisme, heures de service, réglementation, déréglementation

\section{INTRODUCTION}

$M$ any Canadians would struggle to find a single commodity in their homes that has not, at some point, been transported by truck. In 2012, 650 million tonnes of freight were moved by the Canadian forhire trucking industry (Searag et al 2015: 1). In this article, I consider the grounded implications of Hours of Service (HoS) regulations for the contentious mobilities of long haul truckers. ${ }^{1}$ HoS regulations are a complex set of rules governing the on- and off-duty scheduling of commercial vehicle drivers. Truckers' negotiations of these regulations have direct implications for public safety, as well as social and employment equality.

To address these dynamics, I critically analyze HoS regulations using data from my ethnography of the British Columbia-based longhaul trucking industry. I argue that, in the context of deregulation and the movement to 'just-in-time' shipping practices, HoS regulations consolidate the neoliberalization (Peck and Tickell 2002) of the trucking industry. The regulations individualize responsibility for adherence in ways that are problematically decontextualized from industry power dynamics and truckers' lived experiences of labour mobility. Inasmuch as they fail to address the classed, gendered and racialized dynamics of trucking mobilities, HoS regulations are implicated in perpetuating hierarchies of power in the industry. As such, they are inadequate and - in contextually specific ways - counterproductive to promoting employment equity or overall public safety. These issues are particularly evident in the contentious politics of blame concerning heavy truck-involved collisions.

Movements and flows of people, information and goods are profoundly shaped by social policy, meaning critical policy analysis is an important avenue for the investigation of complex mobilities (Peck 2011). In keeping with an emergent focus on policy mobilities (Cochrane

1. Canadian HoS regulations differ North and South of Latitude 60 degrees North. This article addresses regulations for the Southern latitudes. 
and Ward 2012, Peck 2011, Peck and Theodore 2012, Temenos and McCann 2013), I am concerned with the migration of neoliberal governance models into trucking regulations, and I problematize the rational choice presumptions of these policies (see Peck and Theodore 2010). However, rather than following or 'studying through' a policy or specific situation of policy making (see McCann and Ward 2012), I have immersed myself in the mobile life worlds of those regulated to critically analyze HoS policies.

The bulk of the data for this study was generated between 2011-2013. Data generation techniques included qualitative interviews with current and former truckers, participant observation and observant participation (Moeran 2009) at industry associated sites, observations and recordings of truck-to-truck radio interactions and ride-alongs with truckers. The ride-alongs ranged in duration from six hours to several days and took me through two Western Canadian provinces and three Northwestern American states. Although broader research activities were inclusive of non-white truckers, all but one of the recorded interviews were with white participants. Six women and twenty-eight men participated in indepth interviews. All names are pseudonyms and identifying information has been removed.

\section{Overview: Canadian HoS Regulations}

While Canadian truckers' work hours have been regulated since the 1940s, the National Safety Code governing current regulations was first implemented in the late 1980s (CMRTHS 2008). The rules are defined in two sets of regulations under two separate statutes. The Motor Vehicle Operators Hours of Work Regulations replaces Canada Labour Code entitlements and hours for work for federally regulated carriers. ${ }^{2}$ The Commercial Vehicle Drivers Hours of Service Regulations set minimum and maximum daily and weekly or bi-weekly on- and off-duty time for commercial vehicle operators. The regulations came under review in the mid-1990s, with major revisions coming into federal force in January $2007 .{ }^{3}$

Currently, commercial vehicle operators are not allowed to drive after 14 hours of being on-duty, 13 of which can be spent driving. Most truckers engage in a considerable amount of non-driving labour, which is

2. On trucking, employment standards and the Canada Labour Code, see Chow and Weston 2008, Chow 2006.

3. Interprovincial and international carriers are regulated federally. Provinces regulate intraprovincial carriers and are responsible for all HoS enforcement. 
legally classified as on-duty time. This includes servicing a vehicle; travelling as a passenger; waiting to be loaded or unloaded; being inspected; waiting at a road stoppage and so on. Drivers must take a minimum 10 hours daily off-duty time, 8 of which must be consecutive. The remaining 2 off-duty hours can be split throughout the day in minimum 30 minute increments.

Drivers can choose from one of two weekly or bi-weekly driving cycles. Cycle one allows a driver to work 70 on-duty hours per week, after which they must rest for 36 consecutive hours. Cycle two allows a driver to be on duty for 120 hours over two weeks, with a 24 consecutive hour break after 70 hours. A 72 consecutive hour off-duty rest is required before another 120 hour cycle can begin (Minister of Justice 2015). Truckers hauling into the United States are required to adhere to American Hours of Service Regulations while they are in that country. ${ }^{4}$ All on- and off-duty time must be strictly documented in legally-binding daily logs, or logbooks.

HoS rules are an attempt to balance economic and public safety considerations related to the operation of commercial vehicles. From the outset, the regulations were intended to counter the potential risks associated with trucker fatigue (CMRTHS 2008). There are significant economic incentives for keeping trucks moving. Industry profit is predicated on the ability to move product; the more a trucker drives, the greater potential profit. The broad-based movement to just-in-time shipping practices further means the functioning and profits of non-trucking industries can be contingent on transport times. However, longer driving hours increase the potential for driver fatigue. A considerable body of research has demonstrated that driver fatigue can significantly increase the risk of driver error and collision (Adams-Guppy and Guppy 2003, Dawson et al 2011, Heaton 2005, Thiffault 2011, Van Cauter and Turek 1990). Reviewing the high numbers of trucking-related fatalities in Australia and the United States, Quinlan et al (2006) found that truck driving is among the most dangerous occupations in terms of likelihood of death or serious injury. They argue that drivers are under huge economic pressure to speed and drive excessive hours.

Of course, truck accidents are not only dangerous for truckers; they also pose substantial risks for other road users. Between 2001-2005, about 20 percent of motor vehicle collision fatalities in Canada involved heavy trucks and 85 percent of fatalities in heavy truck-involved collisions were occupants of light vehicles or other road users (Transport

4. American commercial vehicle operators have a maximum 11 hours of perday drive time, after 10 consecutive hours off (compared to 13 and 8 hours for Canada, respectively). 
Canada 2011: 29-30). While the fatality rate per 100 million vehicle kilometres traveled is considerably lower for heavy trucks than for all vehicles (Ibid. 29), the size, weight and average travel speeds of these vehicles increases the likelihood of serious injuries or fatalities when collisions do occur (Mayhew et al. 2004: 2). Injuries and deaths from collisions involving heavy trucks in Canada declined significantly over the past two decades, as have per-vehicle injury and death rates for all vehicles (Mayhew et al. 2004 ii). These declines occurred even as more freight is being moved by truck. ${ }^{5}$

Concerns about driver fatigue are a central theme in a broader politics of blame concerning truck-involved collisions. This is true even though fatigue and falling asleep at the wheel are infrequently reported as factors in heavy-truck involved crashes, and less so for multiple (as opposed to single-) vehicle crashes. Notably, fatigue is more likely to be reported as a factor for the operator of the passenger vehicle than for the trucker (Mayhew et al. 2004: iii). In heavy truck-involved collisions overall, truck drivers are generally less likely than drivers of passenger vehicles to be found to have been driving improperly, and this is especially true of truck-involved collisions that result in fatalities (Mayhew et al. 2004: iii). However, concerns about trucker fatigue are consistently raised in public and policy discussions about truck-involved collisions (see CRASH 2004, Transport Canada 2011: 29-31). This is due, in part, to the demonstrated impact of fatigue on driver competence; the dangers posed by the size, weight and cargo of commercial vehicles; and the myriad ways the organization of trucking labour can exacerbate driver fatigue.

HoS regulations are a primary regulatory tool for addressing these issues. However, their relative efficacy and optimal design are contentious. Critics argue that regulations should address circadian rhythms and the effects of time-of-day driving (Heaton 2005, Thiffault 2011). Thiffault (2011) notes that HoS regulations set maximum (rather than optimal) driving limits, and potentially encourage companies and drivers to consistently operate at maximum regulatory limits. It has been widely observed that overall compliance is poor (Heaton 2005, Hokey 2009, Saltzman and Belzer 2002). Enforcement difficulties are broadly recognized, and electronic surveillance devices are often suggested as a potential solution (Thiffault 2011, Transport Canada 2015). There is a general tendency to focus on driver behaviour to address the issue of fatigue and HoS non-compliance, primarily because of the economic incentives for truckers to drive long hours. Significantly less prescriptive

5. Mayhew et al. (2004) argue the consistency of such trends for all vehicles suggests the causal factors are not specific to trucking. 
attention has been placed on the influence of industry practices and the organization of labour therein (for exceptions, see Heaton 2005, Rothe 2002). These influences are especially relevant in current neoliberal contexts - an issue to which I now turn.

\section{Neoliberalism, HoS Regulations and Individual Responsibilization}

Contemporary HoS regulations were enacted following the deregulation of trucking that began in the 1980s. Deregulation reduced barriers to industry participation and eliminated government oversight and control of rates and pay structures. These shifts are part of a broader neoliberal agenda emphasizing limited government, free market reforms, targeted governance and individualization (see Brodie 2002, Connell 2010, Peck and Tickell 2002). In keeping with research linking neoliberal policies with gender, racial and class inequalities (Creese 2007, Griffen Cohen and Pulkingham 2009, Kingfisher 2002, Thomas 2010), HoS regulations are implicated in industry hierarchies of labour and mobility.

Deregulation heightened industry competition and in some sectors instigated 'race-to-the-bottom' contract bidding practices. Belman and Monaco (2001) argue that deregulation and de-unionization depressed real wages and increased wage inequality among truckers in the United States. In Canada, only about one-quarter of all truckers -- short- and long-haul -- are unionized. Truckers' average wages have remained stagnant since 1998 and employed truckers are less likely to receive benefits than workers overall (Dubé and Pilon, 2006). Special exemptions from provincial Employment Standards Acts mean truckers are not subject to the same minimum wage requirements, nor are they entitled to daily overtime pay. ${ }^{6}$ Truckers in my study consistently reported stagnating or declining wages since deregulation, especially in relation to the costs of fuel, business and living.

Inasmuch as truckers' incomes are primarily determined by the number of kilometres they drive, HoS limitations act as a de-facto cap on drivers' wages (Heaton 2005), one instituted with no compensating mechanism to ensure truckers are fully remunerated for their labour. Within the industry, it is widely acknowledged that truckers are not nearly paid for all of the work that they do, especially if one factors in time spent performing non-driving labour. In this regard, the form of truckers' employment may influence their relationship to HoS regulations. Truckers are generally owner-operators, lease operators, or company drivers.

6. Although not standard industry practice, some provisions for overtime pay for federally regulated carriers may exist (see Lockwood 2013). 
Owner-operators own their trucks. They may be self-employed as independent contractors, or may lease their truck to a trucking company. Alternatively, some truckers lease a truck and/or trailer from a trucking company. Company drivers are employees who drive trucks owned by their employer.

An owner-operator may be incentivized to maximize driving hours to secure the greatest potential profit from their truck, and to entrench positive relationships with shippers. ${ }^{7}$ Lease operators and company drivers are commonly paid cents per kilometre or as a percentage of the load rate. Company drivers - and union-protected company drivers especially - may have provisions for hourly wages in relation to non-driving labour or even safety stoppages (such as unsafe road conditions). Depending on their employment circumstances, then, company drivers may have fewer obvious financial incentives for driving over hours. Meanwhile, a range of factors (such as the form of contractual labour, job security, individual driver status, or even a truckers' relationship with a particular shipper, receiver or dispatcher) may influence a lease operator's incentives, capacity and empowerment to abide by HoS regulations.

The degree to which truckers are able to stay within legal driving limits is thereby often a reflection of industry hierarchies. Truckers and those associated with the industry generally acknowledge that company drivers for large, secure carriers with union protections are more likely to be empowered to meet HoS regulations. One worker for Commercial Vehicle Safety Enforcement (CVSE) explained that there is "no such thing as a true logbook, unless it's a union [driver]" (Fieldnotes Spring 2011). Truckers employed in more precarious sectors of the industry are more vulnerable to exploitative work conditions. Speaking generally, this includes owner-operators, contract drivers and employees of smaller, less secure firms. These are also the drivers whose interests and perspectives are least likely to be reflected by larger industry associations - associations often consulted by the government and researchers on issues of industry regulation. ${ }^{8}$

Although National Safety Code provisions allow authorities to penalize carriers for cumulative safety violations, individual truckers are primarily responsibilized for HoS compliance. ${ }^{9}$ This individualization of responsibility amid corporate deregulation has been an important part

7. On the masculine, ideological and cultural incentives for truckers' overwork, see Agar 1986, Ouellet 1994.

8. Although it is beyond the scope of this paper, advocacy groups for truckers and the transportation industry exist and are contentious.

9. On provincial National Safety Code administration, see Ministry of Transportation 2013. 
of the neoliberalisation of the trucking industry. Brodie (2002) argues an emphasis on individual responsibility is a central pillar of neoliberal policies in Canada, and that such individualization is problematically decontextualized from power hierarchies. Current HoS regulations similarly fail to account for industry power dynamics. Many drivers in my study problematized the notion that they have much choice when it comes to falsifying logbooks and breaking HoS regulations.

Commonly, drivers reported needing to record non-driving on-duty labour as off-duty time to maintain their employment and, in many cases, safe driving practices. For example, drivers might spend twice as long doing a pre-trip inspection of their vehicle as permitted by their employer, but alter their logbooks to reflect employers' demands (Fieldnotes, Winter 2012). Alternatively, they might spend hours at a road stoppage, or waiting to be loaded, and feel they had to mark that as off-duty time. As Cole explained:

...your rate is based on a perfect day. There's no allowances for the gray time. [...] You're sittin' there waitin' for a road to be cleared, or someone else to off-load ahead of ya, or...so you put 'er down as time off. [...] And that's the part that's makin' you a liar. But you have no choice. Or you do. You could quit your job.

Just-in-time shipping practices and per-load payment arrangements can effectively responsibilize truckers for a host of potential travel delays that are beyond their control. In this way, many truckers experienced overwork and unpaid labour as a job requirement.

The power and autonomy of shippers, receivers and carriers can allow them to exploit truckers' mobilities to their maximum benefit - and to the detriment of the health and safety of truckers and the general public. Trevor explained:

...there's the blue-chip companies, there's the middle of the road companies, and then there's the bottom feeders. Well, the bottom feeders get the work because they'll be cheaper than anyone else. [...] Well, the only thing that you can skimp on is what you are paying the driver... And that driver, in order to make a living, instead of doing one trip every other day, will have to do one and a half trips in a day.

A few truckers in my study with secure jobs and union protections working for large carriers reported strong support from their employers for HoS adherence. However, many others faced pressure from employers, shippers and dispatchers to drive beyond their allowable hours - and this was especially true of truckers with precarious employment. This suggests that HoS non-compliance is more likely to result from exploita- 
tion and inequality in the industry, rather than simple profited-motivated choice. In this way, current HoS regulations tend to assume a level of autonomy that many drivers simply do not have. These dynamics are especially troubling in light of concerns over racial segregation in trucking and the reliance on migrant workers, including through the Temporary Foreign Worker Program.

\section{Trucking Mobilities and the Temporary Foreign Worker Program (TFWP)}

Widespread concerns have been raised about the abuse of migrant labourers in guest worker programs in Canada and abroad (Foster 2012, Shelley 2007, Siemiatyck 2010). In the early- and mid-2000s, the TFWP expanded to include lower-skilled occupations. A growing proportion of all truckers are immigrants (Dubé and Pilon, 2006), and problematic industry claims of a driver shortage combined with class-based skills categorizations have facilitated an expanded reliance on non-white migrant workers for trucking labour (Foster 2012). In 2012, 5,037 short and long haul truckers were working under the TFWP in Canada, although that number dropped to 1,707 in 2014 when the program was subject to widespread public scrutiny and a government overhaul (Government of Canada 2016).$^{10}$ These labourers are especially vulnerable to exploitation from employers and racism from other truckers, which ultimately disempowers all truckers from resisting exploitative working conditions - including the pressure to work and drive illegally excessive hours.

Scholars have pointed out the classed, gendered and racialized dimensions of Canadian guest worker programs, particularly with regard to low-skilled labourers (Fudge and MacPhail 2009, Nakache 2013, Trumper and Wong 2007). Researchers have further demonstrated that skills classifications are contingent (Armstrong 2013) and problematically defined in relation to power hierarchies (Creese, Dyck and McLaren 2011). Among participants in my study, the classification of truck drivers' labour as low skill was especially contentious. ${ }^{11}$ Many participants associated the designation with class-based stereotypes about truckers as uneducated and incompetent.

10. This excludes workers enrolled under Provincial/Territorial Nominee Programs, which offer greater rights and opportunities relative to the TFWP (see Carter 2012, Nakache and D'Aoust 2012).

11. Transport Drivers are classified as Skill Level C, which also includes food and beverage servers, customer service and mail carriers. There is only one lower skills classification. 
The truckers I spoke with overwhelmingly considered themselves professionals in the sense of being skilled, capable, competent and responsible. They pointed to the complex, specialized and life-or-death nature of their work skills:

...if we're counting on non-skilled people to drive at 55 or 60 miles an hour up and down the roads, in this country, with a hundred and forty thousand pounds on, um, I think we're in big trouble. [...] When you compare it to a hairdresser, it's considered a skilled trade. Nothing against hairdressers, but, um, the worst thing, in most cases, you're gonna get out of a hairdresser is a bad haircut. So, whereas, with a tractor-trailer operator, you can have, uh, some pretty devastating collisions. [...] I would challenge any [politician] to come on down an' we'll see how well they can shift a non-sychronized transmission, an' get a 53 foot trailer through downtown wherever, right? (Jake)

Many truckers argued that their status as professional drivers imposed added responsibilities when it came to safe and best driving practices.

At the same time, white truckers' claims to highly skilled work mobilities are increasingly racialized in the context of neoliberal shifts in industry organization and the heightened reliance on migrant workers. Elsewhere, I have detailed how strategic appeals to whiteness provide a narrative resource for white drivers to negotiate their mobile work lives (McLean 2016). In part, this is accomplished by denigrating the skills and competencies of non-white truckers, and South Asian drivers in particular. South Asian drivers are commonly depicted by white truckers as dangerously lacking in language and driving skills, as well as the masculine instrumentality presumed by many to be crucial to trucking labour. For example, Stuart claimed:

...when you take somebody from another country, and you bring them over here, who maybe just had a horse and buggy over there - we don't know. They get a driver's license because they go around a test course 25 times, and they know to turn the wheel left at the manhole cover, and they'll pass their test. And they do. And then two weeks later they're pulling 140,000 pounds in a B-train through the Fraser Canyon - that's a big problem.

As I later explore, presumed racial hierarchies of skill are also implicated in the politics of blame concerning truck-involved collisions.

Many white truckers blame South Asian drivers for, in Isaac's words, "destroying the industry." Importantly, some white truckers actively challenged racism in the industry, and still others problematized the industry exploitation of non-white and migrant truckers. For example, 
Trevor observed that "When everyone else says 'Nope, I won't do that. Because that's not safe.' A visible minority goes, 'Well, do I feed my family or do I do that?" Nonetheless, virulent racism is prevalent among white truckers, and the current neoliberal context of TFWP implementation can only increase racial segregation and driver exploitation.

Foster (2012) explains that guest worker programs have a tendency to create "pockets of foreign worker-dominated occupations that are disconnected from local workers and labour markets" (Foster 2012: 23, see also Ruhs and Martin 2002). These tendencies are exacerbated because restrictive Temporary Foreign Worker (TFW) work permits prevent labourers from changing employers (Nakache 2013). Researchers argue that the TFWP can undermine the labour movement and repress domestic worker demands for better wages and working conditions (Foster 2012, Fudge and Macphail 2009, Nakache 2013). This includes reducing the likelihood of unionization (Foster 2012). These dynamics not only increase the vulnerability and isolation of migrant workers, they also increase the likelihood of exploitation for all truckers.

One way for unscrupulous trucking companies to increase profits is by pushing drivers to haul beyond HoS driving limits. When this allows them to submit lower bids for contracts or hauls, downward pressure can be exerted on trucking rates. Additional research is needed to explore TFW truck drivers' lived experiences of working conditions and labour mobilities. However, current indications are that TFWs are likely to be especially vulnerable to employer pressure to violate HoS regulations. Foster (2012) points out that, in its most recent iterations, the TFWP significantly increases opportunities for employers to exploit migrant workers. The expansion of the program has seen heightened susceptibility to violations of employment rights, as well as increasing actual violations of migrant workers' rights (Foster 2012, Ruhs and Martin 2008).

Current dynamics mean that truckers labouring under the TFWP are particularly vulnerable to workplace exploitation, including pressure to drive excessive hours. When and if unscrupulous employers engage in such labour practices, migrant truckers' isolation and disempowerment may be exacerbated by racism from white drivers. Moreover, and as I now explore, the capacity for all truckers to make autonomous and contextually adaptable safety decisions is undermined by the problematic ways HoS regulations are decontextualized from truckers' embodied negotiations of their workplace mobilities. 


\section{HoS and Embodied Negotiations of Trucking Space}

HoS regulations replicate the spatial control and removal of embodied authority historically evident in the governance of working class men's labour. Scholars have widely associated working class masculinity with 'shop floor culture,' or repetitive, dehumanizing labour undertaken in the contained spaces of the shop floor (Pyke 1996, Weis, 2004, Willis 1979). Truckers' relative autonomy and independence has been an incentive for working class men to labour in the industry (Agar 1986, Ouellett 1994, Rothe 1991). However, HoS regulations and enforcement erode truck drivers' claims to professionalism and undermine their capacities for flexible and autonomous decision-making. Inasmuch as the regulations are decontextualized from the lived mobilities of trucking, they can effectively criminalize truckers for a systemic social reliance on their overwork and unpaid labour.

Analysts such as Thiffault (2011) suggest that current rules provide sufficient opportunities for drivers to rest on shift, and any failure to do so results from of driver attitude and education (65). Yet, as discussed, although truckers are theoretically allotted two hours of non-consecutive daily off-duty time, many drivers are under pressure to use that time to complete non-driving trucking labour. Truckers also generally need to plan their stops at locations with food, toilet facilities, fuel and so on. So, if a trucker has a necessary planned stop four hours from their starting point but gets drowsy 45 minutes into the drive, they must push through or risk cutting into their allowable drive time - a luxury many drivers feel they do not have. Ben argued, "I used to drive, and if I felt tired, I pull over and have a nap! And then I could just get up again, and drive. You can't do that now. [...] They think that they are changing the rules to make it safer! You're not!" Similarly, while truckers with time-of-day sleep susceptibilities attempted to plan accordingly, such plans were easily thwarted by unpredictable delays at road stoppages, construction sites or shipping facilities. In other words, the inflexibility of HoS regulations inhibit truckers' ability to safely adjust their driving and sleep schedules to their unpredictable working conditions. Many truckers argued that this inflexibility essentially made them into unwilling criminals.

Such tendencies are exacerbated by problematic spatial assumptions inherent in the regulations. HoS regulations presume that at the end of a 13 hour driving shift, and at the close of a weekly driving cycle, there will be a safe, clean, full-facility rest area available for truckers. Theoretically, drivers can plan ahead to arrive at such destinations at the end of a shift. However, a plethora of factors beyond their control can alter a route schedule. For example, on one ride-along an owner-operator 
planned to stop at a community with one 24-hour restaurant. Upon arrival, the restaurant was inexplicably closed. Faced with no food and the potential of having to stop early into the next day's shift, the trucker elected to drive over-hours to get to a restaurant (about an hour's drive away) (Fieldnotes, Fall 2011). However, a commercial vehicle inspection station on route to the restaurant was unexpectedly open late. If we stopped for the night at the second community as planned, we would have to pass through another open inspection station in the morning. That would make it obvious to enforcement officers that we were over hours. It would also mean a 10 hour shut down that would make us late for our next load, and hitting our 36 hour shut down a short distance from the trucker's home base. So, instead of stopping after driving roughly an hour over HoS limits, the trucker felt compelled to drive much further and get through the next station that night (when it would be closed). During that final push, the otherwise conscientious trucker made a dangerous driving decision that almost resulted in a collision (Fieldnotes, Fall 2011).

These knock-on effects are a common problem. For instance, on a tightly scheduled route a driver might be delayed three hours. Assuming they are unable to make up that distance and are expected to maximize HoS drive times, at the end of their week that could mean the driver is stranded for 24,36 , or 70 hours three hours away from their destination. In the best of such circumstances, a driver will likely be spending their weekend in a well-facilitated gas station. However, rest areas with even basic facilities such as running water simply do not exist along vast tracks of Canadian highways. The construction of truck stops can also be highly contentious (CBC 2015). In practice, this means current HoS regulations can require drivers to park and wait for 8 to 70 hours in remote areas without access to food or running water - let alone health or recreational facilities.

This situation can be especially challenging for female truckers. Researchers have documented that female truck drivers can incur responses that include the denial of collegial support, exclusion from communicative rituals, vandalism, robbery and physical and sexual harassment and assault (Anderson et al. 2005, Rothe 1991). Female truckers I encountered often had complex safety strategies for negotiating their workplace mobilities. Despite this, many of them had variously experienced sexism, threatening behaviour, stalking and/or sexual harassment or abuse while on the job. Some of the more extreme examples of this occurred in isolated trucking spaces (such as brake checks, loading facilities, or rest stops) during mandated HoS off-duty time. After describing an incident 
of escalating harassment and threatening behaviour by a male worker at a regular loading point, Katelyn recounted:

He didn't come near me too much after that, which was good! [Laughter] But yeah, that was probably...And one time on, it was at a brake check an' somebody seen I was there. And I was taking a nap. Just my head on the steering wheel, having a quick rest...And somebody jumped up on the truck.

In this instance, Katelyn's dog scared the man away. But in cases where female truckers experience or fear gender-based harassment or violence, they may hesitate to leave an unsafe or potentially unsafe location to avoid violating HoS regulations. In this way, current regulations have the potential to increase the risk of gender-based abuse and violence faced by female truckers.

Given the considerable mismatch between HoS regulations and truckers' embodied negotiations of their workplace mobilities, it comes as little surprise that compliance rates are poor. However, there appears to be little appetite for adopting more workplace appropriate regulations or mandating improvements to truck driver wages and working conditions. Instead, there is considerable impetus for increasing the disciplinary surveillance of truckers, primarily through mandating electronic logging devices (ELDs). These devices are mounted inside trucks to track and record vehicle driving times, distances, speeds and so on (Thiffault 2011, Transport Canada 2015).

Truckers in my study had widely divergent perspectives on ELDs. Some unionized company drivers for large carriers were used to ELDs and welcomed their expanded use. Some speculated that ELDs would be beneficial in the long run, because they would force the industry to recognize and compensate truckers for all of the work they do, as well as encourage the adoption of routes appropriate to HoS schedules. Others, such as Neal, argued for freight-dependent adaptability and exceptions:

...if I'm an hour away from the farmer's place [...] and that computer says 'Its time to pull over. I'm going to shut you down.' What do I do? I can't sit there with a load of 120 head of calves on there in 30 degree heat. That farmer will kill me by the time I get there! Plus, I've got a huge damage claim with the dead cattle in the back.

Truckers in all sectors tended to express some anxieties concerning reduced autonomy and increased surveillance, whereas drivers in precarious jobs feared they would be ruined. Still others were already prepared 
with straightforward work-arounds for the supposedly "tamper-proof" devices.

What is clear is that ELDs do not give truckers access to running water or functioning toilets. They will not automatically see truckers compensated for all of the work that they do. Nor do they extricate drivers from complex, embodied and spatial hierarchies of power. The individualized responsibilization and criminalization of truckers for their excessive work hours obscures the accountability of employers, dispatchers, shippers, receivers, governments and consumers for the organization of trucking labour. These dynamics are especially evident in what is probably the most contentious aspect of truckers' mobilities; that is, the politics of blame for industry associated road carnage. ${ }^{12}$

\section{HoS, Trucking Carnage and the Politics of Blame}

A pervasive and often-vicious politics of blame develops in incidents of truck-involved collisions. Such politics are gendered and racialized. Truck drivers are highly cognizant of the prevalence of gendered and class-based stigmas about them, and that awareness can contribute to a sense of vulnerability, a commitment to masculine notions of control and their own participation in blame politics. Inasmuch as current HoS regulations tend to responsibilize or even criminalize truckers without addressing the exploitative contexts in which many drivers labour, they obscure the need for broader accountability for truck-involved collisions.

Truckers' stories about truck-involved collisions regularly depicted how class-based stereotypes invoking the lazy, exhausted, irresponsible and/or inebriated trucker are quick to emerge from the social imaginary to explain away truck-involved collisions. Among truckers, there was a widespread belief that, regardless of the individual circumstances of a crash, in the minds of police, employers and the general public, they are always and immediately assumed to be at fault in any collision. As Ben explained, the lack of fit between HoS regulations and truckers' mobile work lives is directly implicated in this sense of vulnerability: "...all it

12. Some reviewers suggested the word 'carnage' is problematically sensationalistic, especially considering my critique of the individualization of blame for collisions. However, many truckers reported traumatic and visceral experiences with what can only be accurately described as road carnage, and the politics of blame surrounding such incidents is especially relevant to this discussion. My goal has been to avoid sensationalism while remaining accountable to my participants' experiences. This means, in part, refusing to lose sight of the embodied consequences - that is, the carnage - associated with many road collisions, or their implications for truckers' work lives and mobilities. 
takes is somebody else to screw up. If somebody else runs a stop sign and slams into you, you are the guy that's going to get into trouble because you've overworked what the law that somebody that's not a truck driver has written for you."

Ben was profoundly aware of the devastating consequences that the presumption of blame could have. He was involved in a fatal collision - a suspected suicide - for which an RCMP investigation fully exonerated him. But even as Ben left the accident scene, news reports began inaccurately claiming that a trucker had driven erratically and swerved out of his lane. Shortly later, he came across an online discussion of the incident in which participants vehemently condemned the truck driver in the collision and all truckers generally. This experience made him deeply reluctant to ever reach out or seek help in dealing with this profoundly traumatic event.

Exposure to road carnage is a significant risk of trucking labour. Almost all drivers in my study who had been on the road for very long had experiences of being first-on-scene at car wrecks. Many of these truckers recounted delivering lifesaving and/or end-of-life care to fellow motorists. Some of the work that truckers reported doing at accident scenes includes contacting emergency services; comforting injured and dying people; covering mutilated and dismembered bodies with truckers' own clothing or blankets; locating body parts; reaching into severed limbs to pinch off arteries; and transporting injured people to hospital. For many truckers, these traumatic experiences heightened their sense of injustice over the apparent tendency to automatically blame truckers for industry-associated collisions. They were viscerally aware of the carnages of automobility. And while truckers consistently told stories of truck drivers being unfairly blamed for unavoidable collisions, they by no means asserted that truckers were always blameless. Most drivers argued - often stridently - that truckers bear a heightened level of road responsibility. However, they also expressed frustration at the lack of knowledge or education about the operation of heavy trucks on the part of other road users.

Many truckers drew explicit links between the tendency to blame truckers for truck-involved collisions and broader capitalist social processes. In particular, truck drivers were apt to point out that consumers demand overnight delivery and cheap prices, but do not want truckers to work long hours or to be on the roads at all. In Sam's words, "Those same people that are bitching about trucks on the road are the same people that are demanding low prices when they buy their products." Sam and others noted that if the true cost of truck transport were reflected in consumer goods, prices would be significantly higher. Truckers were 
also frustrated by the apparent hypocrisy evident in condemnations of transport drivers. Sam went on to recount a story in which his neighbour regularly complained about dangerous driving by truckers. Sam pointed out that because his neighbour's company hired the cheapest possible freight carriers, they were part of the problem. Despite his efforts, Sam's neighbour remained unable or unwilling to see how his participation in the undervaluing of truckers' labour contributed to the problem of industry and road safety.

I previously highlighted how contemporary dynamics in the trucking industry may exacerbate racism and (especially) the exploitation of non-white migrant truck drivers. The racialized politics of blame for industry carnage play into those processes. Through racialized narratives concerning trucking skills and collisions, many white truckers attempted to defer responsibilization for truck-involved collisions onto non-white, and especially South Asian, truckers. Martin recounted:

When he hit the first corner out o' the brake check, his tires were smokin'. His brakes. He never made it four kilometres down the mountain [...] He was going down wide open. This man should never have been allowed a license. He should never have been allowed to drive that kind of weight in the mountains. That's the problem I have with Hindus.

Throughout my research, I regularly encountered similar narratives responsibilizing South Asian truckers for truck-involved collisions. These depictions were gendered as well as racialized, inasmuch as they asserted the deadly, feminized irrationality of non-white truckers while denying their capacities for masculine instrumentality. Prominent features of the narratives included depicting (primarily) South Asian truckers as willing to haul for unsustainably low rates; as lacking basic language skills or the necessary training for road conditions, trailer weights, stopping distances and so on; as regularly driving illegally excessive hours; and as driving poorly maintained and unsafe equipment.

While such descriptions could be interpreted as indicative of the exploitation of non-white truck drivers in the industry, white truckers in my study most commonly 'explained away' potential evidence of illegal conditions of exploitation as the inherent function of degenerate, racialized subjectivities (see McLean 2016). In doing so, white truckers assert the racial supremacy of their driving skills while simultaneously responsibilizing non-white drivers for trucking collisions. This off-loading of blame onto a potentially vulnerable group of truckers inflames racial tensions in the industry and reduces the likelihood of labour movement solidarity. 


\section{Conclusion: If You Bought It, A Truck Brought It}

Truckers' mobilities are especially contentious because they are at once vital to the operation of contemporary society, yet carry with them the potential for devastating collisions. HoS regulations are the primary mechanism for addressing the life-and-death risks posed by truck driver fatigue. However, the neoliberal individualization at the heart of contemporary HoS regulations precludes a broader accountability for the overwork of truckers. In their current formulation HoS regulations effectively remove embodied authority from truckers in ways that limit their ability to respond to the highly mobile and unpredictable conditions of their labour. Truckers' capacities to negotiate their mobilities are also expressions of gendered, classed and racialized power dynamics.

The assumption that truckers "choose" to violate HoS regulations due to profit motivation obscures the complex ways that carriers, shippers, receivers, governments and consumers rely on the exploitation and over-work of drivers. Even those of us seeking to create alternative, non-automobile based mobilities rely on truckers to deliver our bikes, strollers, helmets, rain gear, shoes and so on. The suppression of wages and working conditions in the industry helps to reduce the prices of consumer goods and to obscure the real costs of contemporary capitalist mechanisms of production and distribution. This systemic reliance on the overwork and underpay of truckers is at once obvious and invisible. Addressing the predictable inequality and road carnage that result from these dynamics requires recognizing the blind spots inherent to a comfortable politics of blame. This further requires looking beyond current HoS regulations to consider what a social justice overhaul of the trucking industry would really mean for the road ahead.

\section{REFERENCES}

Adams-Guppy, Julie and Andrew Guppy. 2003. Truck driver fatigue risk assessment and management: A multinational survey. Ergonomics, 46 (8): 763 779 .

Agar, Michael. 1986. Independents Declared: The Dilemmas of Independent Trucking. Washington, DC: Smithsonian Institution Press.

Anderson, Debra Gay, Susan Westneat and Deborah Reed. 2005. Workplace violence against female long-haul truckers. Security Journal, 18 (2): 31-38.

Armstrong, Pat. 2013. Puzzling skills: Feminist political economy approaches. Canadian Review of Sociology, 50 (3): 256-283. 
Belman, Dale and Kristen Monaco. 2001. The effects of deregulation, de-unionization, technology, and human capital on the work and work lives of truck drivers. Industrial and Labour Relations Review, Extra Issue: Industry Studies of Wage Inequality, 54 (2a): 502-524.

Brodie, Janine. 2002. The great undoing: State formation, gender politics, and social policy in Canada. In Western welfare in decline: Globalization and women's poverty, edited by Catherine Kingfisher, 90-110. Philadelphia: University of Pennsylvania Press.

Carter, Tom. 2012. Provincial Nominee Programs and Temporary Worker Programs. In Legislated Inequality: Temporary Labour Migration in Can$a d a$, edited by Patti Tamara Lenard, Christine Straehle, 178-201. London: McGill-Queen's University Press.

CBC. 2015. Margaret Atwood's tweet 'spooks' Surrey truck parking lot proposal. CBC News. October 302015.

Chow, Garland. 2006. Labour standard issues in the inter-provincial Canadian trucking industry. Federal Labour Standards Commission. June 5, 2006.

Chow, Garland and Rob Weston. 2008. The status of owner-operators under the Canada Labour Code: Is change needed? Transportation Journal, 47 (4): $42-50$.

CMRTHS. 2008. Harmonization of Transportation Policies and Regulations: Context, Progress and Initiatives in the Motor Carrier Sector, Report to the Council of the Federation. Council of Ministers Responsible for Transportation and Highway Safety. June 2008.

Cochrane, Allan and Kevin Ward. 2012. Researching the geographies of policy mobility: confronting the methodological challenges. Environment and Planning A, 44 (1): 5-12

Connell, Raewyn. 2010. Understanding neoliberalism. In Neoliberalism and Everyday Life, edited by Susan Braedley and Meg Luxton, 22-36. McGill-Queen's University Press.

CRASH 2004. A report card on big truck safety; Gov'ts, trucking firms making roads more dangerous, not safer. Canadians for Responsible and Safe Highways. Canadian Centre for Policy Alternatives. February 12004.

Creese, Gillian. 2007. Racializing work/Reproducing white privilege. In Work in tumultuous times: Critical perspectives, edited by V. Shalla and W. Clement, 192-226. Montreal: McGill-Queen's Press.

Creese, Gillian, Isabel Dyck and Arlene Tiger McLaren. 2011. The problem of 'human capital': Gender, place and immigrant household strategies of reskilling in Vancouver. In Gender, generations and the family in international migration, edited by Kraler, Kofman, Kohli, and Schmoll, 141162. Amsterdam: Amsterdam University Press.

Dawson, Drew, Ian Noy, Mikko Härma, Torbjorn Akerstedt, and Gregory Belenky. 2011. Modelling fatigue and the use of fatigue models in work settings. Accident Analysis and Prevention, 43 (2): 549-564. 
Dubé, Vincent and Denis Pilon. 2006. On the road again. Statistics Canada: Perspectives on Labour and Income, 7 (1): 11-21.

Foster, Jason. 2012. Making temporary permanent: The silent transformation of the temporary foreign worker program. Just Labour: A Canadian Journal of Work and Society, 19: 22-46.

Fudge, Judy and Fiona MacPhail. 2009. The Temporary Foreign Worker Program in Canada: Low-skilled workers as an extreme form of flexible labour. Comparative Labor Law and Policy Journal, 31 (5): 5-45.

Government of Canada. 2016. Annual labour market impact assessment statistics 2007-2014. March 112016.

Griffen Cohen, Marjorie and Jane Pulkingham. 2009. Public policy for women: The state, income security, and labour market issues. Toronto: University of Toronto Press.

Heaton, Karen. 2005. Truck driver hours of service regulations: The collision of policy and public health." Policy, Politics, and Nursing Practice, 6 (4): 277-284.

Hokey, Min. 2009. The impact of hours-of-service regulations on transportation productivity and safety: A summary of findings from the literature. Journal of Transportation Management 21 (2): 49-63.

Kingfisher, Catherine. 2002. Western welfare in decline: Globalization and women's poverty. Philadelphia: University of Pennsylvania Press.

Lockwood, Rolf. 2013. Overtime pay for drivers. Today's Trucking. July 25, 2015.

Mayhew, Daniel, Herb Simpson, and Douglas Beirness. 2004. Heavy trucks and road crashes. Traffic Injury Research Foundation. March 2004.

McCann, Eugene and Kevin Ward. 2012. Assembling urbanism: Following policies and 'studying through' the sites and situations of policy making. Environment and Planning A, 44 (1): 42-51.

McLean, Amie. 2016. "Four guys and a hole in the floor": Racial politics of mobility and excretion among BC-based long haul truckers. Transfers: Interdisciplinary Journal of Mobility Studies, 6(1): 45-61.

Minister of Justice. 2015. Commercial vehicle drivers hours of service regulations SOR/2005-313. Amended November 282009.

Ministry of Transportation and Infrastructure. 2013. National Safety Code review: Improving commercial vehicle safety in BC. Government of British Columbia. April 2013.

Moeran, Brian. 2009. From participant observation to observant participation. In Organizational Ethnography: Studying the Complexity of Everyday Life, edited by Ybema, Yanow, Wels, and Kamsteeg, 139-155. London: Sage.

Nakache, Delphine. 2013. The Canadian Temporary Foreign Worker Program: Regulations, practices, and protection gaps. In Producing and Negotiat- 
ing Non-Citizenship: Precarious Legal Status in Canada, edited by Luin Goldring and Patricia Landolt, 71-97. Toronto, ON: University of Toronto Press.

Nakache, Delphine and Sara D'Aoust. 2012. Provincial/Territorial Nominee Programs: An avenue to permanent residency for low-skilled temporary foreign workers? In Legislated Inequality: Temporary Labour Migration in Canada, edited by Patti Tamara Lenard, Christine Straehle, 158-177. London: McGill-Queen's University Press.

Ouellet, Lawrence. 1994. Pedal to the Metal: The Work Lives of Truckers. Philadelphia: Temple University Press.

Peck, Jamie. 2011. Geographies of policy: From transfer-diffusion to mobilitymutation. Progress in Human Geography, 35 (6): 773-797.

Peck, Jamie and Nik Theodore. 2010. Mobilizing policy: Models, methods, and mutations. Geoforum, 41: 169-174.

Peck, Jamie and Nik Theodore. 2012. Follow the policy: A distended case approach. Environment and Planning A 44 (1): 21-30.

Peck, Jamie and Adam Tickell. 2002. Neoliberalizing space. Antipode. 34 (3): 380-404.

Pyke, Karen D. 1996. Class-based masculinities: The interdependence of gender, class, and interpersonal power. Gender \& Society, 10 (5): 527-549.

Quinlan, Michael, Claire Mayhew, and Richard Johnstone. 2006. Trucking tragedies: The hidden disaster of mass death in the long-haul road transport industry. In Working Disasters: The Politics of Recognition and Response, edited by Eric Tucker, 19-64. Amityville, NY: Baywood Publishing Company, Inc.

Rothe, John. 1991. The Trucker's World: Risk, Safety, and Mobility. New Brunswick: Transaction Publishers.

Rothe, John. 2002. Dispatchers and drivers: On-the-road economics and manufactured risk. In Driving Lessons: Exploring Strategies that Make Traffic Safer, edited by John Rothe, 143-159. Edmonton, AB: The University of Alberta Press.

Ruhs, Martin and Philip Martin. 2008. Numbers vs. rights: Trade-offs and guest worker programs. International Migration Review, 42 (1): 249-65.

Saltzman, Gregory and Michael Belzer. 2002. The case for strengthened motor carrier hours of service regulations. Transportation Journal, 41 (4): 5171.

Searag, Greg Maloney, and Larry McKeown. 2015. Trucking dangerous goods in Canada, 2004 to 2012. Statistics Canada. February 11, 2015.

Shelley, Toby. 2007. Exploited: Migrant Labour in the New Global Economy. London: Zed Books. 
Siemiatycki, Myer. 2010. Marginalizing migrants: Canada's rising reliance on temporary foreign workers. Canadian Issues, Spring: 60-63.

Temenos, Cristina and Eugene McCann. 2013. Geographies of policy mobilities. Geography Compass, 7 (5): 344-357.

Thiffault, Pierre. 2011. Addressing human factors in the motor carrier industry in Canada. Canadian Council of Motor Transport Administrators. May 2011.

Thomas, Mark. 2010. Neoliberalism, racialization, and the regulation of employment standards. In Neoliberalism and Everyday Life, edited by Susan Braedley and Meg Luxton, 68-89. Montreal: McGill-Queen's University Press.

Transport Canada. 2011. Road safety in Canada. March 2011.

Transport Canada. 2015. Minister Raitt supports two electronic technologies for trucks and buses. News Release. March 192015.

Trumper, Ricardo and Lloyd Wong. 2007. Canada's guest workers: Racialized, gender, and flexible. In Race and Racism in 21st-Century Canada: Continuity, Complexity, and Change, edited by Sean Hier and Singh Bolaria. Peterborough, ON: Broadview.

Van Cauter, Eve and Fred Turek. 1990. Strategies for resetting the human circadian clock. New England Journal of Medicine, 322 (18): 1306-1308.

Weis, Lois. 2004. Class Reunion: The Remaking of the American White Working Class. New York, NY: Routledge.

Willis, Paul. 1979. Learning to Labour: How Working-Class Kids get WorkingClass Jobs. Aldershot: Gower.

\section{ACKNOWLedgements}

Thank you to my participants and all those who facilitated my ethnographic encounters. I appreciate the work of the reviewers whose thoughtful comments have significantly improved this paper. I am grateful to have received research funding from the Social Sciences and $\mathrm{Hu}-$ manities Research Council of Canada.

Amie McLean is a Ph.D. candidate in Sociology at Simon Fraser University. Her research interests include inequality, critical race feminism and qualitative methods. Her mother was a trucker and heavy equipment operator. She has published on Indigenous post-secondary education in Canada and racial mobility politics in trucking.

E-mail: amie mclean@sfu.ca 